\title{
МЕТОД ПОВЕРХНЕВОГО ПЛАЗМОННОГО РЕЗОНАНСУ ЯК ПЕРСПЕКТИВА РОЗВИТКУ БІОСЕНСОРИКИ
}

\author{
Меренич Н. А., Калашнікова Л. $\boldsymbol{C}$., к.б.н., доц. каф. БМІ \\ dudusja1996@bigmir.net, le.kalashnikova@aae.kpi.ua \\ Факультет Біомедичної інженерії \\ Національний технічний університет України \\ «Київський політехнічний інститут імені Ігоря Сікорського» \\ Київ, Україна
}

\begin{abstract}
Реферат - В останні десятиліття спостерігається величезне зростання в розвитку чутливих пристроїв поверхневого плазмонного резонансу як з фундаментальної точки зору, так і високочутливих пристроїв для оптичного визначення малих біологічних чи хімічних об'єктів у газах та рідинах. Рефрактометрія поверхневого плазмонного резонансу є одним із оптичних методів дослідження, а саме вони на сьогодні вважаються найбільш перспективними для впровадження в иироку практику.

Методика поверхневого плазмонного резонансу дозволяє вивчати прочеси молекулярної взаємодї в реальному часі без хімічного приєднання до досліджуваних об'єктів різних міток. При иъьму експериментатор одержує додаткову інформацію про кінетику досліджуваних прочесів з високою чутливістю, витрачаючи на проведення аналізу малі кількості проби.

Технологія ППР дає можливість визначати наявність в розчинах хімічних, біохімічних речовин і мікрочастинок; їхню концентрацію; а також вивчати кінетику біохімічних взаємодій та ї̈ залежність від різних чинників. Таким чином ППР сенсори знайшли своє практичне застосування в біохімї для визначення забруднень, домішок, контролю інгредієнтів у рідинах. 3'явилась можливість швидко ідентифікувати віруси, бактерії, токсини, генно-модифіковані організми як в лабораторіях, так і в польових умовах.

У статті описано біосенсори на основі явища поверхневого плазмонного резонансу в наноплівках золота, продемонстровано можслиість їх застосування для ідентифікації у водних розчинах домішок солей малих концентрацій, приведено результати дослідження по визначенню чутливості приладу «ПЛАЗМОН» за допомогою модельних зразків.

Усі експерименти були проведені на базі Інституту фізики напівпровідників на приладі «ПЛАЗМОН-6». Дані рефрактометри розробляються для наукових досліджень. Ці прилади можуть успішно використовуватися під час вивчення явищ, які характеризуються зміною оптичних властивостей тонких приповерхневих шарів, а також для проведення аналізів медико-біологічного профілю. Серію малогабаритних аналітичних приладів «ПЛАЗМОН» було розроблено в ІФН ім. В. С. Лашкарьова НАНУ під керівництвом с.н.с. Ушеніна Ю. В.

Ключові слова - біосенсор; поверхневий плазмонний резонанс; кут ППР; показник заломлення; золота наноплівка.
\end{abstract}

\section{I. Вступ}

Останні десятиліття відзначені інтенсивним розвитком досліджень в області створення малогабаритних сенсорних приладів для кількісного контролю хімічних та біологічних речовин на молекулярному рівні. Явище поверхневого плазмонного резонансу може використовуватися всюди при виникненні потреби визначення концентрації певних аналітів у різних середовищах. ППР-сенсори дають можливість мініатюризації та автоматизації устаткування при значному скороченні часу аналізу i спрощенні аналітичної процедури.

Методи реєстрації біомолекулярних взаємодій на основі плазмонного резонансу використовують вимір точної позиції кута плазмонного резонансу в приладах 3 монохро- матичним променем [1-3] - Biacore, ТИСПР, BIO-SUPLAR, або вимір довжини хвилі, що відповідає плазмонному збудженню при використанні джерела білого світла [4; 5]. У роботах [6-8] проаналізоване питання про оптимальний вибір металу і довжини хвилі збуджуючого світла 3 погляду досягнення максимальної чутливості і хімічної інертності робочої поверхні перетворювача. Найбільш перспективним застосуванням рефрактометрії ППР можна вважати імуносенсорне [9]. У приладі «ПЛАЗМОН» використовується поляризоване світло лазера, чутливий елемент 3 нанозолота (оскільки цей метал забезпечує потрібну межу детектування і стабільність), а при нанесенні додаткового шару цей рефрактометр стає високоточним біосенсором. 
Результати досліджень, висвітлених у статті демонструють можливість застосування приладу «ПЛАЗМОН» в якості біосенсора. Для досягнення поставленої цілі було ідентифіковано домішки різних концентрацій у водних розчинах, проаналізовано результати, а також визначено межу чутливості приладу.

\section{II. Виклад матеріалів досліджень}

Мета першого дослідження - аналіз залежності між концентрацією досліджуваного розчину та зміщенням ППР-кута. Модельними зразками для проведення експерименту були обрані водні розчини хлориду натрію різних концентрацій. Для підтвердження достовірності результатів дослід проводився не лише на приладі «ПЛАЗМОН». Розчини додатково аналізувалися оптичним рефрактометром, 3 метою порівняння показників заломлення, а також кондуктометром визначалася провідність досліджуваних зразків. Результати наведені у таблиці 1.

Таблиця 1. Результати вимірювання модельних зразків

\begin{tabular}{|c|c|c|c|c|}
\hline № & $\begin{array}{c}\text { Конц., } \\
\text { \%мм.. }\end{array}$ & $\begin{array}{c}\text { Провід- } \\
\text { ність, } \\
\text { мкСм/см }\end{array}$ & $\begin{array}{c}\text { ПЗ виміряний } \\
\text { рефрактометром } \\
\text { ІРФ-454 }\end{array}$ & $\begin{array}{c}\text { ПЗ виміряний } \\
\text { приладом } \\
\text { «ЛАЗМОН» }\end{array}$ \\
\hline 1 & 0,1 & $1832 \pm 1$ & $1,3332 \pm 0,0002$ & $1,33162 \pm 0,00002$ \\
\hline 2 & 0,5 & $5656 \pm 1$ & $1,3340 \pm 0,0002$ & $1,33224 \pm 0,00002$ \\
\hline 3 & 1 & $7984 \pm 1$ & $1,3346 \pm 0,0002$ & $1,33320 \pm 0,00002$ \\
\hline 4 & 2 & $>9000 \pm 1$ & $1,3365 \pm 0,0002$ & $1,33474 \pm 0,00002$ \\
\hline
\end{tabular}

Для кращої візуалізації, за даними таблиці побудовано графік залежності вмісту солі в розчині від показника заломлення, виміряного приладом «ПЛАЗМОН», тобто концентраційну залежність.

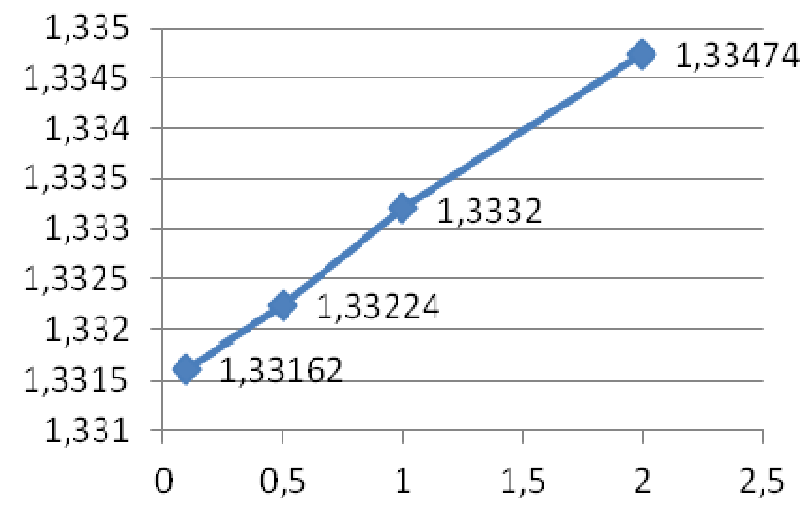

Puc. 1. Графік концентраційної залежності від ПЗ виміряного рефрактометром «ПЛАЗМОН»

Визначення межі чутливості приладу відбувалося наступним чином: до розчину відомої концентрації додавалася дистильована вода, i знову проводилися вимірювання за всіма показниками. Метою було знайти таку концентрацію, при якій зміщення кривої ППР сольового розчину відносно чистої води буде непомітним. Таким чином отримано результати, відображені в таблиці та визначено, що «ПЛАЗМОН» чутливий до домішок концентрацій до однієї тисячної відсотка.

\section{Таблиця 2. Визначення межі детектування} «ПЛАЗМОНУ»

\begin{tabular}{|c|c|c|c|}
\hline $\begin{array}{c}\text { Конц., } \\
\text { \% мас. }\end{array}$ & $\begin{array}{c}\text { Провідність, } \\
\text { мкСм/см }\end{array}$ & $\begin{array}{c}\text { А, виміряна } \\
\text { «Плазмоном» }\end{array}$ & $\begin{array}{c}\text { ПЗ, виміряний } \\
\text { «Плазмоном» }\end{array}$ \\
\hline 0,0667 & $753 \pm 1$ & $0,00020 \pm 0,00002$ & $1,33160 \pm 0,00002$ \\
\hline 0,0500 & $678 \pm 1$ & $0,00017 \pm 0,00002$ & $1,33157 \pm 0,00002$ \\
\hline 0,0400 & $624 \pm 1$ & $0,00016 \pm 0,00002$ & $1,33156 \pm 0,00002$ \\
\hline 0,0333 & $591 \pm 1$ & $0,00012 \pm 0,00002$ & $1,33152 \pm 0,00002$ \\
\hline 0,0286 & $544 \pm 1$ & $0,00012 \pm 0,00002$ & $1,33152 \pm 0,00002$ \\
\hline 0,0167 & $362 \pm 1$ & $0,00011 \pm 0,00002$ & $1,33151 \pm 0,00002$ \\
\hline 0,0020 & & $0,00010 \pm 0,00002$ & $1,33150 \pm 0,00002$ \\
\hline 0,0013 & & $0,00009 \pm 0,00002$ & $1,33149 \pm 0,00002$ \\
\hline 0,0010 & & $0,00007 \pm 0,00002$ & $1,33147 \pm 0,00002$ \\
\hline
\end{tabular}

\section{III. Висновки}

Підсумовуючи вищевикладене, можна стверджувати, що прилад «ПЛАЗМОН» є високоточним, чутливим та ефективним біохімічним сенсором. У статті продемонстровано аналітичні можливості застосування ППР-приладу, завдяки дослідам на модельних зразках. Подальші дослідження повинні бути спрямовані на дослідження безпосередньо біологічних рідин. Метод поверхневого плазмонного резонансу може стати одним із ключових напрямків у біосенсориці, оскільки $\epsilon$ автоматизованим, швидким, високочутливим, що дає змогу працювати 3 досліджуваними рідинами у кількості кількох мікролітрів.

\section{ПЕРЕЛІК ПОСИЛАНЬ}

[1] Jonsson U., Fagerstam L., Ivarsson B. Real-time biospecific interaction analysis using surface plasmon resonance and a sensor chip technology // BioTechniques. - 1991. - Vol. 11 P.620-627.

[2] Woodbury R. G., Wendin C., Clendenning J., Mendelez J., Elkind J., Bartholomew D., Brown S., Furlong C. Construction of biosensors using a gold-binding polypeptide and a miniatureintegrated surface plasmon resonance sensor // Biosensors and Bioelectronics. - 1998. - Vol.13 - P.11171126.

[3] [Електронний ресурc] - 2015. - www.micro-analytical systems.de

[4] Homola J. The sensitivity of surface plasmon resonance sensors with spectral interrogation //Sensors and Actuators, B. - 2013. - Vol. 41 - P.207-211.

[5] Ho H. P., Wu S. Y., Yang M., Cheung A.C. Application of white light-emitting diode to surface plasmon resonance sensors // Sensors and Actuators, B. -2012. - Vol.80 - P.89-94. 
[6] Davies J. Surface plasmon resonance - the technique and its applications to biomaterial processes // Nanobiology. - 2014. - Vol.3. - P.5-16.

[7] De Bruijn H. E., Kooyman R. P. H., Greve J. Choice of metal and wavelength for surface-plasmon resonance sensors: some considerations // Applied Optics. - 2012. - Vol.31,№4. P.440-442.
[8] Salamon Z., Macieod H. A., Tollin G. Surface plasmon resonance spectroscopy as a tool for investigating the biochemical and biophysical properties of membrane protein systems. II: Applications to biological systems // Biochimica et biophysica acta. - 2014. - №1331. - P. 131-152.

[9] Malmqvist M. Biospecific interaction analysis using biosensor technology // Nature. - 2013. - Vol.361. - P.186-187.

\section{МЕТОД ПОВЕРХНОСТНОГО ПЛАЗМОННОГО РЕЗОНАНСА КАК ПЕРСПЕКТИВА РАЗВИТИЯ БИОСЕНСОРИКИ}

Меренич Н. А., Калашникова Л. $\boldsymbol{G}$., к.б.н., доц. каф. БМИ dudusja1996@bigmir.net, le.kalashnikova@aae.kpi.ua

Факультет Биомедицинской инженерии Национальный технический университет Укриины «Киевский политехнический институт имени Игоря Сикорского» Киев, Украина

Реферат - В последние десятилетия наблюдается огромный рост в развитии чувствительных устройств поверхностного плазмонного резонанса как с фундаментальной точки зрения, так и высокочувствительных устройств для оптического определения мальх биологических или химических объектов в газах и жидкостях. Рефрактометрия поверхностного плазмонного резонанса является одним из оптических методов исследования, а именно они сегодня считаются наиболее перспективными для внедрения в широкую практику.

Методика поверхностного плазмонного резонанса позволяет изучать процессы молекулярного взаимодействия в реальном времени без химического присоединения к изучаемым объектам различных меток. При этом экспериментатор получает дополнительную информацию о кинетике исследуемых процессов с высокой чувствительностью, тратя на проведение анализа малые количества пробы.

Технология ППР позволяет определять наличие в растворах химических, биохимических веществ и микрочастии; их кониентрацию; а также изучать кинетику биохимических взаимодействий и ее зависимость от различных факторов. Таким образом ППР сенсоры нашли свое практическое применение в биохимии для определения загрязнений, примесей, контроля ингредиентов в жидкостях. Появилась возможсность быстро идентифицировать вирусы, бактерии, токсины, генно-модифицированные организмы как в лабораториях, так и в полевых условиях.

В статье описаны биосенсоры на основе явления поверхностного плазмонного резонанса в нанопленке золота, продемонстрирована возможность их применения для идентификации в водных растворах примесей солей малых концентраиий, приведень результаты исследования по определению чувствительности прибора «ПЛАЗМОН» с помощью модельных образиов.

Все эксперименты были проведены на базе Института физики полупроводников на приборе «ПЛАЗМОН -б». Рефрактометры ППР серии «ПЛАЗМОН» разрабатываются для научных исследований. Эти приборы могут успешно использоваться при изучении явлений, которые характеризуются изменением оптических свойств тонких приповерхностных слоев, а также для проведения анализов медико-биологического профиля. Серию малогабаритных аналитических приборов «ПЛАЗМОН» на основе явления ППР был разработан в Институте физики полупроводников им. В.Е. Лашкарева НАН Украины под руководством с.н.с. Уиенина Ю. В.

Ключевые слова - биосенсор; поверхностный плазмонный резонанс; угол ППР; показатель преломления; золотая нанопленка. 


\title{
SURFACE PLASMON RESONANCE METHOD AS A PERSPECTIVE OF DEVELOPMENT OF BIOSENSORICS
}

\author{
N. Merenych, L. Kalashnikova, assistant professor, \\ $\mathrm{PhD}$ in Biological sciences \\ ORCID 0000-0001-5816-134X dudusja1996@bigmir.net \\ le.kalashnikova@aae.kpi.ua \\ Faculty of Biomedical Engineering \\ National Technical University of Ukraine \\ "Igor Sikorsky Kyiv Polytechnic Institute" \\ Kyiv, Ukraine
}

\begin{abstract}
In recent decades, there has been a tremendous growth in the development of sensitive surface plasmon resonance devices, both from a fundamental point of view and highly sensitive devices for the optical detection of small biological or chemical objects in gases and liquids. Refractometry of surface plasmon resonance is one of the optical methods of research, and they are considered today to be the most promising for introduction into wide practice.

The surface plasmon resonance technique makes it possible to study the processes of molecular interaction in real time without chemical attachment to the studied objects of various labels. In this case, the experimenter obtains additional information on the kinetics of the investigated processes with high sensitivity, spending small amounts of the sample on the analysis.

The technology of PPR allows to determine the presence of chemical, biochemical substances and microparticles in solutions; their concentration; and also to study the kinetics of biochemical interactions and its dependence on various factors. Thus, PPR sensors have found their practical application in biochemistry for the determination of contaminants, impurities, and control of ingredients in liquids. There was an opportunity to quickly identify viruses, bacteria, toxins, genetically modified organisms both in laboratories and in the field.

The article describes biosensors based on the phenomenon of surface plasmon resonance in gold nanofilms, demonstrated the possibility of their use for identification of small impurities in aqueous solutions of impurities, gives the results of a study to determine the sensitivity of the PLAZMON device using model samples.

All experiments were carried out on the basis of the Institute of Semiconductor Physics on the "PLAZMON-6" device. Refractometers of ППР of a series "PLASMON" are developed for scientific researches. These devices can be successfully used in studying phenomena that are characterized by a change in the optical properties of thin near-surface layers, as well as for carrying out analyzes of the medical and biological profile. A series of small-sized analytical instruments "PLASMON" based on the phenomenon of PPR was developed at the Institute of Semiconductor Physics. V.E. Lashkaryova NAS of Ukraine under the supervision of senior researcher. U.Ushenin.
\end{abstract}

Keywords - a biosensor; surface plasmon resonance; angle PPR; refractive index; gold nanofilm 